Scientific Journal of

Basic and Applied Sciences

Available online at Science-Tanta

Research Article

GEOLOGY

\title{
Environmental assessment of Lake Manzala inferred from diatom analysis of the lake surface sediments
}

\author{
Abdelfattah Ali Zalat ${ }^{*}$ and Ayat allah Roshdy Saleh \\ Geology Department, Faculty of Science, Tanta University, Tanta 31527, Egypt \\ *Correspondence: Abdelfattah A. Zalat, Geology Department, Faculty of Science, Tanta University, Tanta 31527, \\ Egypt;Email: abzalat@science.tanta.edu.eg
}

KEY WORDS

Diatom assemblages,

Environmental assessment, Manzala Lake,

Egypt

\section{ABSTRACT}

The distribution patterns of diatoms in the surface sediments of Manzala Lake have been studied in detail. A total of 110 diatom species belonging to 48 genera have been identified from samples consist mainly of greenish gray mud with relatively some muddy sand sediments. The distribution pattern of the recorded diatom taxa displayed changes in the floristic composition due to changes in the ecological conditions such as salinity, $\mathrm{pH}$, and some chemical elements, which are related to sea-level fluctuations, freshwater influences, waste discharge from the drains and climatic changes. Multivariate statistical techniques including hierarchical ascending clustering and Canonical correspondence analyses were used to identify ecological groups of diatoms and to estimate which environmental variables were important in diatom distribution. Five diatom ecological groups were identified and classified the lake into five distinct ecological zones.

\section{Introduction}

The northern Egyptian lakes along the Mediterranean coast are highly dynamic and productive shallow ecosystems where the composition, abundance and biomass of the phytoplankton and microalgal communities are commonly observed. These lakes have been undergoing continuous and pronounced changes since the late Holocene to the present (Butzer 1976, Zalat \& Servant-Vildary 2007). Urbanization, great population and industrial development during this time have exposed these lakes to pollution from different sources and become hypertrophic. Lake Manzala is one of the most important and largest of these lakes and represents a highly dynamic aquatic system. It has undergone considerable physical, chemical and biological changes during the past and recent time. It has explained marked environmental changes, particularly after construction of the Aswan High Dam in 1965. 
At the present time, large amounts of untreated industrial, domestic, sewage wastes and agrochemicals are discharged annually into the lake through several drains and canals which are located in the south, southeastern and southwestern regions (Fig. 1). This water is loaded with considerable amounts of heavy metals, ammonia, organic matter, fertilizers and suspended materials (Zalat \& ServantVildary 2005). Therefore, this drainage water constitutes an important source of nutrients to the lake, and in turn affects the distribution patterns of the phytoplankton, other microalgae and toxins.

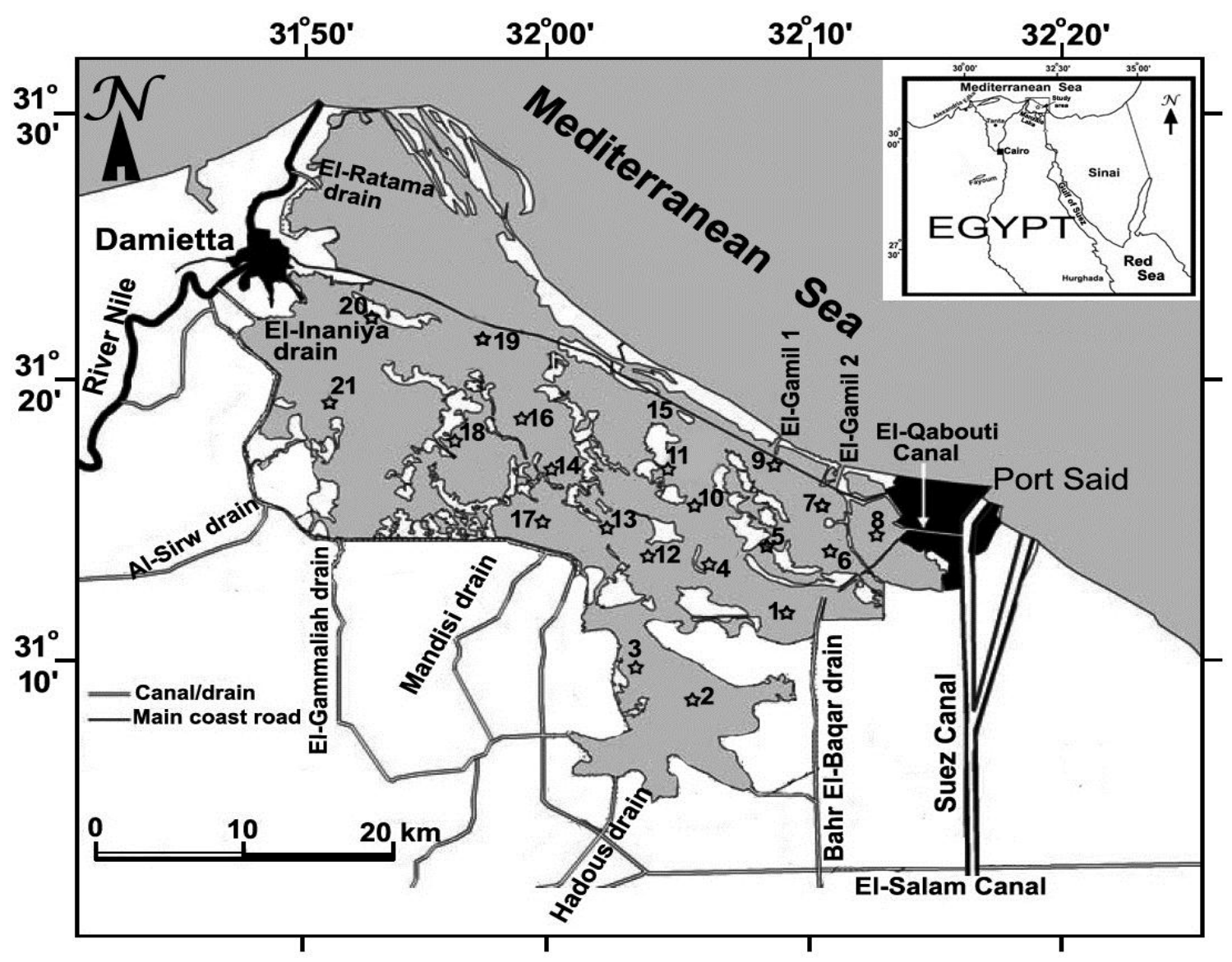

Figure (1): Location map of Manzala Lake showing the position of the studied sites.

Diatoms are one of the most abundant and productive phytoplankton species within Manzala Lake. These unicellular photosynthetic microalgae containing highly ornamented structure of amorphous opaline silica called a frustule, which is usually well preserved in the lake sediments. They are commonly used as bio-indicators for water environmental assessment (Stoermer and Smol 1999, Zalat 2002, Zalat and Servant Vildary 2005). Knowledge of their ecology enables exploitation of a number of species as indicators of water temperature, water salinity, $\mathrm{pH}$, pollutants, paleodepth, paleonutrient concentrations and overall assessments of water quality and the ecological state of aquatic ecosystems (Juggins 1992, HemphillHaley 1995, Gasse et al., 1997; Rakowska 2001, Battarbee et al. 2005, Zalat and Servant Vildary 2007, Zalat 2015). In the coastal lakes, such as the present study, the characterization of modern diatom assemblages may yield excellent criteria to identify paleoenvironmental conditions of the lake and provide a valid basis for reconstructing former lake-level and changes in the ecological conditions during recent history.

Manzala Lake has attracted attention of many scientists because of its important economic aspects. Several investigations have been carried out concerning its ecosystem. These 
studies dealt with different environmental aspects of the lake including geological aspects, hydrological regime, physicochemical properties, bacterial indices, phytoplankton composition, benthic invertebrates and fishery status (Dowidar and Hamza, 1983; Khalil and El-Awamri, 1988; Khalil and Bayoumi, 1988; Khalil, 1990; El-Ghobashy, 1990; Said, 1992; El-Bokhty, 1996; Frihy et al., 1998; AbdelBaky and Zyadah, 1998; Abdel-Satar, 2001; Fathi et al. 2001; Flower, 2001; Fathi and Abdelzahar, 2003; Abbassy et al., 2003; ElEnani, 2004; Yacoub et al. 2005). Only very limited diatom studies were carried out on the lake (e.g. Zalat 2000; Zalat \& Servant Vildary 2005, 2007).

The main objectives of this investigation were to characterize the composition of the diatom community with determine the dominant diatom species and the ecological diatom groups to assess the environmental conditions resulted from the pollutants and human hazards that affecting on the lake. Moreover, how diatom changes across broad salinity, $\mathrm{pH}$ gradients and nutrients within Manzala Lake.

\section{Description of study area}

Manzala Lake is located along the Mediterranean in the northeastern extremity of the Nile Delta, between longitudes $31^{\circ} 45^{\prime}$ $32^{\circ} 15^{\prime} \mathrm{E}$ and latitudes $31^{\circ} 00^{\prime}-31^{\circ} 30^{\prime} \mathrm{N}$ (Fig. 1). It is separated from the Mediterranean Sea by a sandy beach ridge at the north and bordered by the Suez Canal in the east and Damietta Branch in the West. It covers an area of about $1275 \mathrm{Km} 2$, and has a maximum length of nearly $64.5 \mathrm{~km}$, with a maximum width of about $49 \mathrm{~km}$ (Zalat 2000). The lake water is generally brackish, ranging in salinity from a low of $2 \%$ in the western and southern regions to $16-23 \%$ in the south-eastern and near the outlets at the north. The lake is very shallow with maximum depth of about $2.50 \mathrm{~m}$, and has recently decreased further in size, due to land reclamation effects and fish farming (Zalat and Vildary 2005, 2007).

The lake is connected with the Mediterranean Sea by the straits of El-Gamil, Ashtoum AlGamil, Al-Baghdadi, El-Deiba and recently Al-Burg at the northwest corner of the lake. It reaches the Suez Canal through a small navigating canal known as Al-Qabouti. These six openings supply the lake with marine water (Wahby et al., 1972). The western and southern shores have many inlets by which great amounts of wastewater drain into the lake. The most important drainage ditches are: Bahr El-Baqar, Bahr Hadous, Ramsis, Al-Sirw, Abu Garida and Faraskur drains. The northwestern part of the lake is connected to Damietta branch of the River Nile by two canals El-Ratama and El-Souffara. There are three different types of input water into the lake: (1) fresh water from Damietta branch of the river Nile; (2) saline water from the Mediterranean Sea through the different straits; and (3) drainage water from the drains along the western and southern shores (e.g., Bahr E1-Bakar, Hadous, Ramsis, etc.).

Manzala lake contains a large number of islands, which consist of former shorelines sand dunes and clay hummocks (Khalil 1990). The lake area is shrinking in size through the time, from $1907 \mathrm{~km}^{2}$ to $770 \mathrm{~km}^{2}$ in 1997 (ElWakeel and Wahby 1970; UNDP, 1997) due to land reclamation projects and the greater losses of the lake areas were detectable along the western and southern borders of the lake (Frihy et al., 1998). As a result of presence of a large number of islets in the lake, the area of open water is only about $700 \mathrm{~km} 2$ (El-Rakaiby and Youns, 1993). Most of the north-western section of the lake has either been reclaimed or converted to fish ponds. The least disturbed area of the lake is to the southwest, this area does not show signs of water pollution or large areas of aquatic plants (Ramdani et al., 2009).

The lake has experienced a sharp decline in water quality due to the inflow of drainage and wastewater from agricultural run-off, industrial effluents and domestic sewage, which are discharged through drains into the lake. Where, the lake receives heavy loads of organic and inorganic pollutants via several agricultural drains. The main drains contributing to the pollution of Lake Manzala are Bahr El Baqar, Hadous, Al Serw and Faraskaur. Generally, about of 7500 million $\mathrm{m}^{3}$ wastewater are discharged yearly into the lake (Abdel Baky et al., 1998). Bahr El-Baqer 
Drains carrying domestic and industrial sewage, while the Hadous, Ramsis, El-Serw and Faraskour Drains carrying the agricultural effluents. This amount of water was reduced to about 4000 million cubic meters after construction of El-Salam Canal (Badawy et al. 1995; Abdel Baky et al., 1998).

\section{Materials and Methods}

Twenty-one surface sediment samples were collected in April 2013 from different environmental niches in Manzala Lake. During the sampling time, the following limnological variables were measured: water depth, surface water temperature, water $\mathrm{pH}$ was reported by a glass electrode $\mathrm{pH}$ meter, and electrical conductivity was measured using electric conductimeter (Table 1). The surface sediment samples were taken from the upper $5 \mathrm{~cm}$ of the bottom sediments using a Van Veen grab sampler. Samples were sealed and transported to the laboratory for diatom analysis. The sediment samples were dried in an oven at $50{ }^{\circ} \mathrm{C}$ for $24 \mathrm{~h}$, and then weighed to determine their total dry weight. The investigated samples composed mainly of dark blue to greenish gray mud and sandy mud with common mollusk shells in some localities.

For quantitative diatom analysis, one gram of dry sediment was chemically treated to clean and concentrate the diatoms. The diatom separation technique proposed by Zalat (2002) was applied. The calcium carbonate component was removed by adding $\mathrm{HCl}(20 \%)$, and the organic matter was oxidized using $\mathrm{H}_{2} \mathrm{O}_{2}(30 \%)$. Rinsing in distilled water several times to become neutral, and coarse particles were removed by further decantation. Finally, one drop of the final suspension was dried onto cover slips, then mounted onto slides using Canada Balsam or Naphrax ${ }^{\circledR}($ R.I $=1.74)$.

Diatom identification was made using a CarlZeiss photomicroscope with digital Camera at magnifications of $1200 x$, and at least 1000 valves were counted per sample, and specific frequencies were computed. The ecological classifications of diatoms, particularly in relation to salinity and life form were based on the works of (Hustedt 1957, De Wolf 1982, Denys 1991/1992, Vos and de Wolf 1993).
Diatom taxa were identified following Gasse (1986); Krammer and Lange-Bertalot (1986, 1988, 1991a, b) and Lange-Bertalot (2000, 2001). The ecological characteristics of the diatom species were based mainly on the published literature (e.g., Hustedt 1957, 19301966, Ehrlich 1973, 1975, Ehrlich and Ortel 1979, Simonsen 1962, 1979, Krammer and Lange-Bertalot 1986 - 1991, Round et al. 1990, Foged 1993, Denys 1991-1992 and Zalat 2002).

Multivariate statistical analyses were achieved by Past programme v. 2.14 (Hammer et al. 2001). Diatom taxa occurring in at least two samples, with a relative proportion of exceeding 5\% TDV were included in the statistical analyses. The dendrogram of hierarchical cluster analysis was based on Euclidean distance calculated from the first four factorial axes of a correspondence analysis. Cluster analysis is effective in classifying the samples according to their diatom assemblage into different zones. Biplot of the canonical correspondence analysis (CCA) was used to distinguish ecological groups and to relate diatom composition to environmental variables along the two ordination axes. Using this combination of techniques, we delimit diatom ecological zones on the basis of sample clusters that are mutually exclusive in ordination space.

\section{Results}

Quantitative diatom analysis from the surface sediments of the Manzala Lake reveals generally well-preserved diatom frustules with moderate species diversity. A total of 110 species and varieties belonging to 48 genera were recorded from 21 surface sediment samples. There is a marked variation in diatom species composition and its relative abundance between studied sites in the lake. The hierarchical cluster (Fig. 2) and CCA analyses (Fig. 3) of the diatom distribution in the surface sediments showed that a clear separation between the samples and divided the sampling sites and the recorded benthic diatom species into five definitely different zones, each of which is characterized by a distinctive diatom assemblage. CCA relates the composition and distribution of diatom 
assemblages with environmental variables, and correlation matrix of the environmental variables for Manzala lake (Table 2) shows that many of the variables are highly correlated. $\mathrm{Na}_{2} \mathrm{O}$ is highly correlated with salinity and $\mathrm{SiO}_{2} ; \mathrm{MaO}$ with $\mathrm{Fe}_{2} \mathrm{O}_{3}$ and $\mathrm{Al}_{2} \mathrm{O} 3$; is presented as a biplot (Fig. 4). The Pearson $\mathrm{MgO}$ with $\mathrm{Fe}_{2} \mathrm{O}_{3} ; \mathrm{K}_{2} \mathrm{O}$ with temperature; $\mathrm{P}_{2} \mathrm{O}_{5}$ with $\mathrm{Al}_{2} \mathrm{O}_{3}$ and $\mathrm{MaO}$. Depth, $\mathrm{pH}$ and temperature appear to have little correlation with chemical elements and $\mathrm{TiO}_{2}$ has no significance.

Table 1. Physical and Chemical analysis of Manzala Lake sediments.

\begin{tabular}{|c|c|c|c|c|c|c|c|c|c|c|c|c|c|}
\hline \multirow{2}{*}{ S. no } & \multicolumn{3}{|c|}{ Physical characters } & \multicolumn{10}{|c|}{ Chemical analysis } \\
\cline { 2 - 15 } & $\begin{array}{c}\text { Depth } \\
(\mathbf{c m})\end{array}$ & $\mathbf{p H}$ & $\mathbf{T D S}$ & $\mathbf{T}{ }^{\circ} \mathbf{C}$ & $\mathbf{S i O 2}$ & $\mathbf{T i O 2}$ & $\mathbf{A l 2 O 3}$ & $\mathbf{F e 2 O 3}$ & $\mathbf{M a O}$ & $\mathbf{M g O}$ & $\mathbf{N a 2 O}$ & $\mathbf{K 2 O}$ & $\mathbf{P 2 O 5}$ \\
\hline $\mathbf{1}$ & 50 & 8.1 & 41150 & 24.3 & 44.78 & 1.42 & 14.48 & 12.11 & 0.19 & 4.53 & 3.58 & 3.26 & 1.23 \\
\hline $\mathbf{2}$ & 200 & 8.3 & 40250 & 24.5 & 43.52 & 1.13 & 16.12 & 12.43 & 0.23 & 4.25 & 3.42 & 3.45 & 1.52 \\
\hline $\mathbf{3}$ & 200 & 8.4 & 38260 & 24.1 & 41.25 & 1.08 & 14.18 & 11.53 & 0.17 & 4.78 & 3.56 & 3.12 & 1.41 \\
\hline $\mathbf{4}$ & 170 & 8.2 & 41200 & 24.6 & 44.25 & 1.59 & 12.08 & 10.89 & 0.14 & 4.21 & 4.25 & 3.89 & 1.08 \\
\hline $\mathbf{5}$ & 70 & 8.3 & 182130 & 24.5 & 46.78 & 2.01 & 12.45 & 12.54 & 0.08 & 3.89 & 4.23 & 3.58 & 1.13 \\
\hline $\mathbf{6}$ & 100 & 8.3 & 203280 & 24.7 & 51.24 & 1.53 & 12.23 & 12.75 & 0.11 & 4.13 & 4.86 & 3.14 & 1.15 \\
\hline $\mathbf{7}$ & 250 & 8.3 & 363570 & 24.7 & 49.28 & 1.78 & 10.78 & 11.89 & 0.13 & 4.58 & 3.58 & 3.23 & 1.08 \\
\hline $\mathbf{8}$ & 50 & 8.0 & 215290 & 24.5 & 52.13 & 2.04 & 11.25 & 11.53 & 0.15 & 4.75 & 5.23 & 2.45 & 1.06 \\
\hline $\mathbf{9}$ & 82 & 7.6 & 341320 & 24.3 & 59.13 & 1.37 & 11.41 & 8.14 & 0.02 & 2.48 & 17.23 & 2.05 & 1.02 \\
\hline $\mathbf{1 0}$ & 50 & 8.3 & 188460 & 24.7 & 55.78 & 1.82 & 11.53 & 10.89 & 0.09 & 3.12 & 5.11 & 2.89 & 1.05 \\
\hline $\mathbf{1 1}$ & 54 & 8.0 & 184380 & 24.7 & 54.12 & 2.07 & 13.24 & 10.74 & 0.08 & 3.76 & 4.78 & 3.12 & 1.03 \\
\hline $\mathbf{1 2}$ & 70 & 8.1 & 37450 & 24.5 & 50.42 & 1.42 & 12.45 & 11.25 & 0.11 & 3.58 & 3.41 & 3.12 & 1.29 \\
\hline $\mathbf{1 3}$ & 75 & 7.9 & 40580 & 24.6 & 48.59 & 1.89 & 13.25 & 10.79 & 0.08 & 3.78 & 4.23 & 2.78 & 1.25 \\
\hline $\mathbf{1 4}$ & 50 & 8.3 & 96450 & 24.3 & 51.23 & 1.23 & 12.78 & 9.45 & 0.09 & 3.48 & 4.86 & 2.82 & 1.08 \\
\hline $\mathbf{1 5}$ & 75 & 7.5 & 301430 & 24.5 & 44.53 & 2.09 & 11.25 & 10.13 & 0.05 & 3.23 & 5.86 & 2.69 & 1.01 \\
\hline $\mathbf{1 6}$ & 210 & 8.2 & 17560 & 24.1 & 49.86 & 1.56 & 11.29 & 9.48 & 0.06 & 3.11 & 4.83 & 2.75 & 1.03 \\
\hline $\mathbf{1 7}$ & 62 & 8.3 & 39230 & 23.9 & 51.47 & 1.73 & 12.36 & 11.46 & 0.25 & 3.89 & 5.12 & 2.58 & 1.31 \\
\hline $\mathbf{1 8}$ & 50 & 8.3 & 16820 & 23.9 & 46.23 & 1.29 & 10.89 & 10.12 & 0.08 & 2.89 & 4.25 & 3.14 & 1.23 \\
\hline $\mathbf{1 9}$ & 65 & 7.8 & 78340 & 23.7 & 58.46 & 1.48 & 13.05 & 11.42 & 0.04 & 2.51 & 17.89 & 2.12 & 1.05 \\
\hline $\mathbf{2 0}$ & 60 & 8.3 & 19110 & 23.4 & 44.75 & 1.73 & 12.48 & 12.42 & 0.11 & 3.78 & 4.25 & 2.25 & 1.12 \\
\hline $\mathbf{2 1}$ & 50 & 8.1 & 17180 & 23.9 & 48.25 & 1.59 & 12.59 & 13.24 & 0.14 & 3.86 & 3.12 & 2.12 & 1.31 \\
\hline
\end{tabular}

Table 2. Pearson correlation matrix for environmental variables for Manzala Lake. Bolding indicates significant correlation at $\mathrm{p}<$ or $=0.05$

\begin{tabular}{|c|c|c|c|c|c|c|c|c|c|c|c|c|c|}
\hline & depth & pH & Sal. & Temp. & $\mathrm{SiO} 2$ & TiO2 & Al2O3 & $\mathrm{Fe} 2 \mathrm{O3}$ & MaO & MgO & $\mathrm{Na} 2 \mathrm{O}$ & K2O & P2O5 \\
\hline depth & 1.000 & & & & & & & & & & & & \\
\hline pH & 0.30261 & 1.000 & & & & & & & & & & & \\
\hline Sal. & 0.24411 & -0.43323 & 1.000 & & & & & & & & & & \\
\hline Temp. & 0.20498 & -0.07233 & 0.3184 & 1.000 & & & & & & & & & \\
\hline $\mathrm{SiO} 2$ & -0.3563 & -0.3747 & 0.41486 & 0.072397 & 1.000 & & & & & & & & \\
\hline TiO2 & -0.2909 & -0.3229 & 0.15077 & 0.30064 & 0.17886 & 1.000 & & & & & & & \\
\hline Al2O3 & 0.10098 & 0.1875 & -0.4370 & -0.03370 & -0.34528 & -0.42944 & 1.000 & & & & & & \\
\hline $\mathrm{Fe} 2 \mathrm{O3}$ & 0.02883 & 0.44186 & -0.3179 & -0.07463 & -0.38467 & 0.099579 & 0.39174 & 1.000 & & & & & \\
\hline $\mathrm{MaO}$ & 0.22174 & 0.5337 & -0.2802 & -0.03267 & -0.46633 & -0.23372 & 0.58303 & 0.55416 & 1.000 & & & & \\
\hline MgO & 0.34869 & 0.46859 & -0.1161 & 0.29147 & -0.57423 & 0.05106 & 0.35204 & 0.61352 & 0.72371 & 1.000 & & & \\
\hline $\mathrm{Na2O}$ & -0.1765 & -0.62152 & 0.74706 & -0.26557 & 0.68503 & -0.09936 & -0.1393 & -0.45495 & -0.51458 & -0.6656 & 1.000 & & \\
\hline K2O & 0.41088 & 0.48108 & -0.1845 & 0.57104 & -0.5179 & -0.08618 & 0.24139 & 0.19367 & 0.30588 & 0.46476 & -0.5630 & 1.000 & \\
\hline P2O5 & 0.19579 & 0.42235 & -0.4108 & -0.14942 & -0.5252 & -0.53569 & 0.68429 & 0.47362 & 0.7127 & 0.41952 & -0.4033 & 0.23 & 1.000 \\
\hline
\end{tabular}




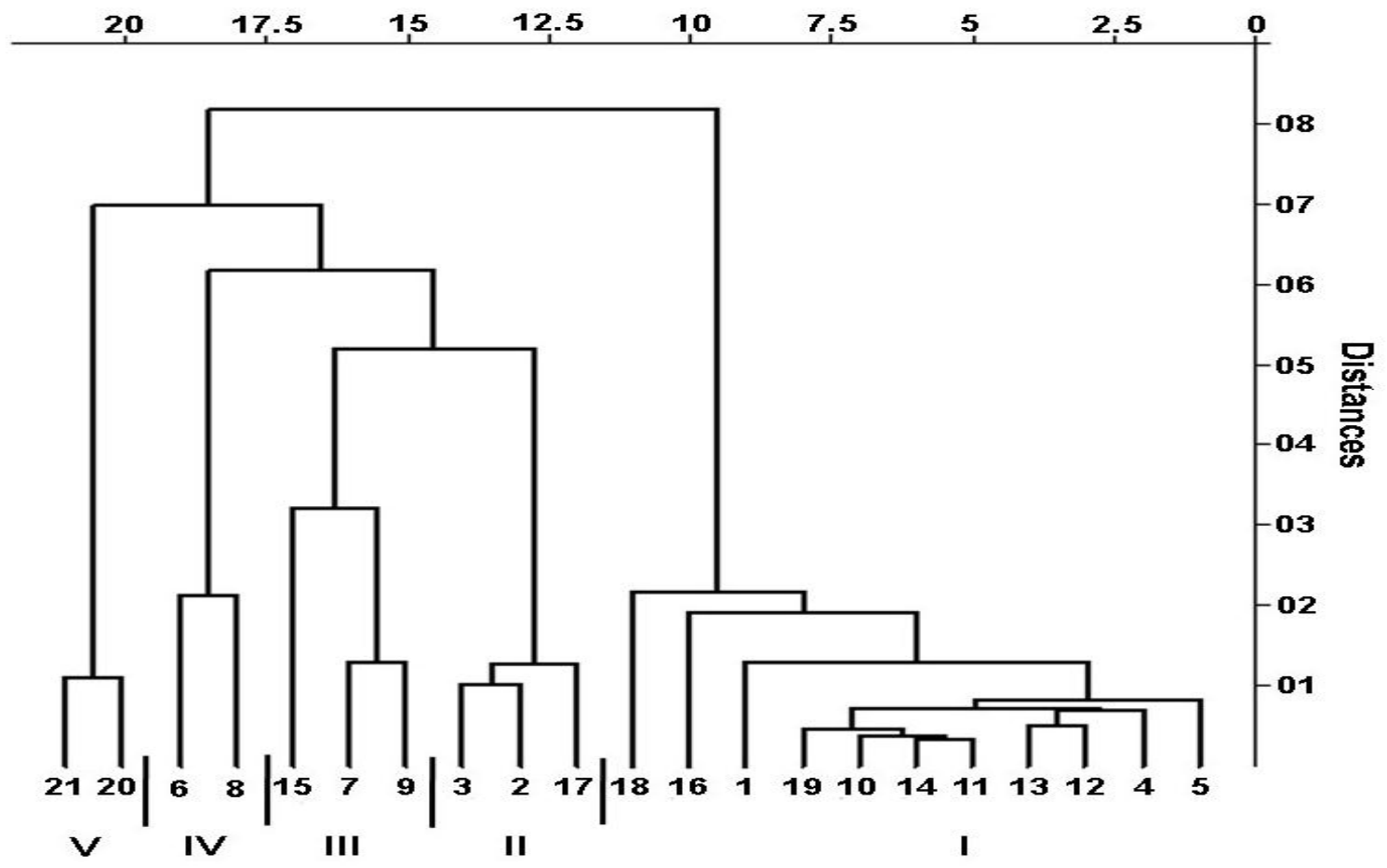

Figure (2): Dendrogram for hierarchical clustering of the sampling sites based on the distribution and relative abundance of diatoms in the surface sediments of Manzala Lake.

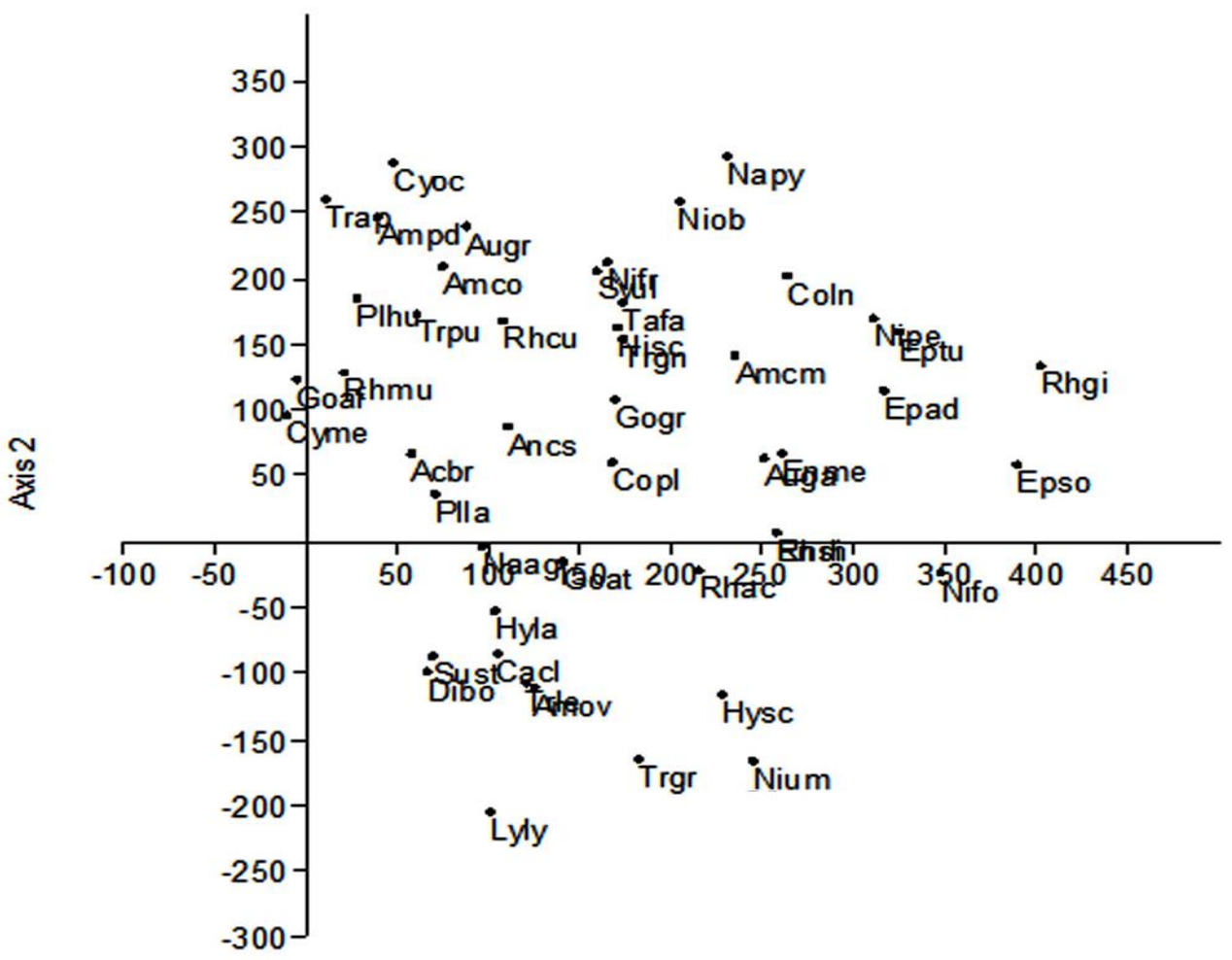

Axis 1

Figure (3): Canonical correspondence analysis (CCA) biplot showing the most common diatom species scores (Eigen value of axis $1=0.6168$, axis $2=0.5957$ ). 


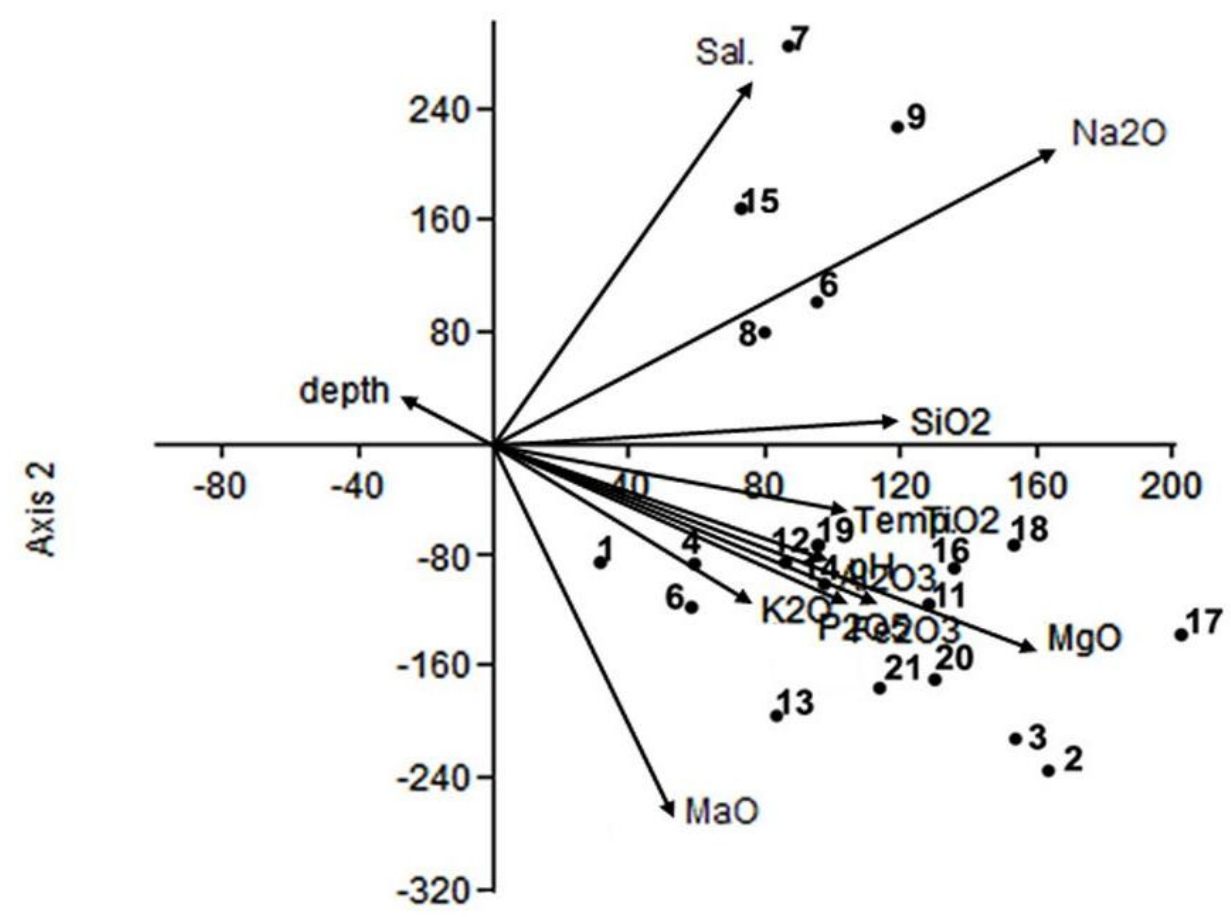

Axis 1

Figure (4): Canonical correspondence analysis (CCA) showing main environmental gradients explaining the variation in diatom species assemblages (Eigen value of axis $1=0.6168$, axis $2=0.5957$ ).

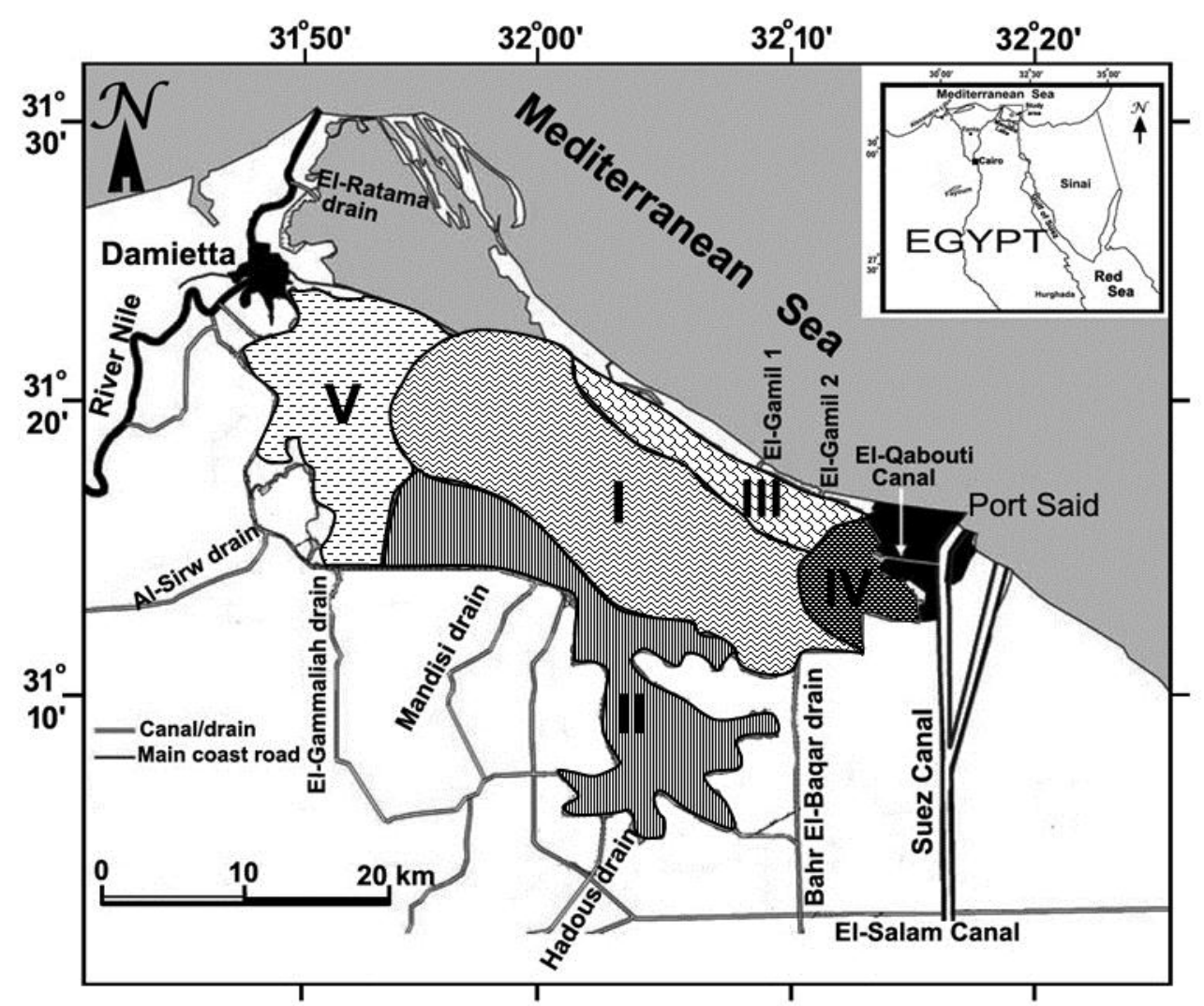

Figure (5): Map showing classification of Manzala Lake into five ecozones $(\mathrm{I}-\mathrm{V})$ based on ecological diatom groups. 
The following is description of the recognized ecological zones in Manzala Lake:

Zone $I$ is characteristic of the middle part of the lake and combined most of the sampling sites $1,4,5,10,11,12,13,14,16,18,19$. In this zone, the diatom assemblage is distinguished by well to moderate preserved of brackish water species associated with few freshwater taxa. Cyclotella meneghiniana a planktonic form was the most dominant species in this zone. The diatom association contained common to frequently appearance of the epiphytic forms such as Cocconeis placentula, Gomphonema gracile, Epithemis adnata, E. sorex Rhopalodia acuminate and Rhopalodia gibba. The benthic forms were distributed irregularly by frequent occurrence of Campylodiscus bicostatus, C. clypeus, Diploneis bombus, Hyalodiscua laevis, Navicula aegyptiaca, Nitzschia obtuse, $N$. scalaris. Other recorded taxa were distributed sporadically.

Zone II is distinguished the southern part of the lagoon and including sampling sites 2, 3 and 17 . The recognized diatom assemblage was represented by great abundance of epiphytic taxa. Cocconeis placentula was the most dominant species associated with frequently occurrence of Cocconeis diminuta, Cymbella affine, Encyonema mesianum, E. minutum, E. silesiacum, Gomphonema affine, G. insigne, G. parvulum, Epithemia sorex, Fragilaria leptostauron, Synedra ulna. The benthic diatoms were present in significant abundance by occurrence of Amphora ovalis, A. pediculus, A. veneta, Campylodiscus clypeus, Diploneis ovalis, Navicula tenelloides, Nitzschia perminuta, Placoneis gastrum, Surirella biseriata. The planktonic forms occurred by frequent appearance of Cyclotella meneghiniana with rare abundance of Aulacoseira granulata.

Zone III is represented by sampling sites 7, 9 and 15 that located at the northern part of the lake. The diatom assemblage of this zone is dominant by well to moderate preserved marine polyhalobous taxa in-combined with significant numbers of highly brackish water taxa.
The littoral coastal diatoms Grammatophora marina and Tryblionella granulata have maximum abundance, accompanying by common to frequently occurrence of polyhalobous taxa such as Tryblionella punctate, Actinocyclus sp., Amphora coeffaeaformis, Diploneis chersonensis, D. didyma, Eupodiscus radiates, Tropidoneis pusilla, Trachyneis aspera, Thalassiosira decipiens. The highly brackish water forms were represented by infrequently occurrence of Hyalodiscua laevis, H. scoticus, Diploneis bombus, Navicula aegyptiaca, N. pygmaea, Rhopalodia acuminata, Campylodiscus clypeus, Surirella fastuosa and Tabularia fasciculate.

Zone IV is covered the eastern part of the lagoon with sampling sites 6 and 8. Highly brackish water taxa are characteristic this zone. Hyalodiscua laevis had great abundance with common appearance of benthic taxa such as Anomoeoneis sphaerophora, Diploneis bombus, Mastogloia braunii, M. smithii, Navicula aegyptiaca, Nitzschia umbonata, $N$. obtuse, N. scalaris, N. sigma, Tryblionella apiculata, T. granulata,T. punctate. The brackish planktonic form Cyclotella meneghiniana was occurred infrequently, while the slightly brackish water forms were represented by sporadically occurrence of some epiphytic taxa such as Cocconeis placentula, Epithemia adnata and Rhopalodia acumminata and $R$. gibba.

Zone $\mathrm{V}$ is comprised sampling sites 20, 21 which are located at the western part of the lake. The diatom assemblage is characterized by commonly occurrence of well-preserved alkaline freshwater, epiphytic diatoms associated with frequently distribution of brackish water forms.

Epithemia sorex has maximum abundance and associated with common occurrence of Rhopalodia gibba, Rhopalodia rhopala and frequently appearance epiphytic taxa such as Epithemia adnata, E. turgida, Cocconeis placentula, Gomphonema gracile, G. affine, $G$. gracile, G. insigne, G. parvulum, Rhoicosphenia curvata, Synedra ulna, S. acus, Cymbella cistula, Encyonema mesianum, E. minutum. The benthic diatom taxa were 
represented by frequent occurrence of Amphora ovalis, A. veneta, Diploneis ovalis, Navicula cincta, N. cryptocephala, N. rhynchocephala, N. tenelloides, Nitzschia perminuta, Placoneis gastrum, Sellaphora bacillum, S. pupula, Surirella biseriata, S. ovalis, Terpsinoe. Americana. The planktonic taxa Aulacoseira granulata and Cyclotella meneghiniana are distributed in low amounts.

\section{Discussion}

The distribution pattern of the diatom assemblages varied significantly between the studied sampling sites, and indicates changes in the floristic composition due to changes in some ecological conditions such as salinity, $\mathrm{pH}$, Temperature and chemical analysis of the sediments. The variations in these ecological factors may relate to sea-level fluctuations, freshwater influences and waste water from the southern drains, human impacts and climatic changes. The vectors of the environmental factors of the bi-plot of CCA indicated that the most important controlling factor on the diatoms in the Manzala Lake was salinity, $\mathrm{SiO}_{2}$ and some chemicals elements. According to the salinity (halobian) preference the identified diatom species have been classified into three groups: Polyhalobous species thrive in fully marine conditions; Mesohalobous diatoms, which are known as brackish water forms and Oligohalobous diatoms denote to freshwater forms (Hudstedt 1953, 1957, Denys 1991-1992, Vos and de Wolf 1993). Of the recognized diatoms 57 taxa are belonging to oligohalobous group associated with significant numbers of about 32 mesohalobous taxa, while the polyhalobous forms of littoral marine origin accounted by 21 species. Others environmental factors such as $\mathrm{pH}$, temperature and chemical elements are affected also on the diatom distribution.

The results of the hierarchical ascending clustering analysis of the investigated samples, based on the diatom composition and distribution, and CCA differentiated Manzala Lake into five ecological zones. The first zone I is covered most of the studied sampling sites along the middle region of the lake. The similarity between these samples is attributed to a great abundance of a planktonic brackish water form Cyclotella meneghiniana associated with important numbers of mesohalobous and oligohalobous forms. The diatom association is correlated well with low TDS, $\mathrm{pH}$ varies from 8.0 to 8.3 , and $\mathrm{K}_{2} \mathrm{O}$ and $\mathrm{Al}_{2} \mathrm{O}_{3}$ concentrations. The great abundance of brackish water taxa and alkalibiontic forms in this zone reflects elevated salinity and alkalinity. As well as, high abundance of planktonic Cyclotella meneghiniana associated with great occurrence of benthic forms point to eutrophic, warm relatively shallow water environment.

The second zone II is occupied the southern part of the lake by samples 2, 3 and 17. The good similarity between these samples is attributed to a great occurrence of epiphytic taxa with maxima abundance of Cocconeis placentula. The ecological preferences of this species is known as oligohalobous, halophilous, alkaliphilous with $\mathrm{pH}$ values 7.58.0, common in fresh and slight salty water; meso- to eutrophic lakes (Cleve-Euler 1953, Hustedt 1957, Ehrlich 1973); oligosaprobic; a widespread eurytopic species, epiphytic on aquatic plants and other objects; more commonly found in circumneutral to alkaline waters; apparently salt "indifferent" not observed in great numbers in slightly brackish waters (Patrick \& Reimer 1966); Simonsen (1962) reports this species in waters up to 1720 g/l salinity, while Mölder and Tynni (1972) identified it in both freshwater and slightly brackish coastal habitats. Lange-Bertalot (1979) and Krammer \& Lange-Bertalot (1986) comment that this species is sensitive to organic pollution. According to the classification of Steinberg \& Schiefele (1988) this is an eutraphic species, with maximum development in nutrient rich and very well oxygenated waters. The great abundance of epiphytic taxa denotes well developed macrophytes in warm sallow fresh to slightly brackish water condition. CCA piblot explains good relation with $\mathrm{MgO}, \mathrm{Fe}_{2} \mathrm{O}_{3}, \mathrm{Al}_{2} \mathrm{O}_{3}$ and $\mathrm{K}_{2} \mathrm{O}$. High values of these elements may attribute to the drainage water from the southern drains such as Hados, Ramsis and bahr El Bakar drains. 
The third zone III is distinguished the northern part of the lake by samples 7, 9 and 15. CCA biplot shows a distinct relationship with salinity and $\mathrm{Na}_{2} \mathrm{O}$. Other chemical elements show negative correlation. The similarity between these samples is attributed to a great abundance of marine littoral polyhalobous diatom species, with significant numbers of mesohalobous taxa. Grammatophora marina and Tryblionella granulata have maximum abundance in this zone. The diatom assemblage reflects warm, shallow, eutrophic conditions with elevated salinity and alkalinity due to the influence of the Mediterranean Sea water, which entering the lake through ElGamil and Ashtoum Al-Gamil outlets.

The fourth zone IV covered small area of the lake at the eastern part close to Suez Canal and represented only by two samples 6 and 8 . The strong similarity between the two samples is attributed to a great abundance of intertidal polyhalobous and highly brackish water diatom species, with significant numbers of mesohalobous forms. CCA biplot (Fig. 4) showing that the diatom assemblage of this zone is correlated well with $\mathrm{Na}_{2} \mathrm{O}$ and $\mathrm{SiO}_{2}$ and no relationship with other chemical elements such as $\mathrm{MgO}, \mathrm{Fe}_{2} \mathrm{O}_{3}, \mathrm{Al}_{2} \mathrm{O}_{3}$ and $\mathrm{K}_{2} \mathrm{O}$. Hyalodiscus laevis had great abundance in this zone. This species is considered as euryhaline, common in marine and brackish waters (Hendey 1964, Hustedt 1927-1966). The diatom assemblage contains significant numbers of marine littoral taxa Tryblionella apiculata, T. granulata,T. punctata associated with common occurrence of mesohalobous species, which explained the invasion of marine water from the Suez canal through AlQabouti canal during rising sea level. The frequently occurrence of some oligohalobous taxa such as Cocconeis placentula, Epithemia adnata and Rhopalodia acumminata and $R$. gibba.in this zone explained allochthonous origin and freshwater influence from the adjacent areas or reworked process. The diatom assemblage in tis zone reflects warm, shallow, eutrophic, highly brackish water conditions characteristic the eastern part of the lake

The last zone $\mathrm{V}$ included only two sampling sites 20 and 21 that located at the western part of the lake. The strong similarity between samples is attributed to a great abundance of freshwater diatom species. CCA biplot (Fig. 5) showing that the diatom assemblage of this zone is correlated well with different chemical elements such as $\mathrm{Fe}_{2} \mathrm{O}_{3}, \mathrm{Al}_{2} \mathrm{O}_{3}$ and $\mathrm{MgO}$. Moreover, diatom assemblage shows no relationship with the $\mathrm{MaO}, \mathrm{SiO}_{2}, \mathrm{NaO}_{2}$ and depth. Epithemia sorex has maximum abundance in this zone. This species is known alkalibiontic taxon, common in littoral standing water, both fresh and brackish (Hustedt 1930, 1957); it seems to prefer high conductivity water often rich in calcium (Patrick \& Reimer 1975); fresh and brackish water, epiphytic, alkalibiontic with $\mathrm{pH}$ over 8 (Ehrlich 1973); oligohalobous, pleioeuryhaline, benthonic (Pankow 1976); oligohalobous "indifferent", alkalibiontic (Foged 1980, 1993). The diatom association contains also several alkalibiontic taxa such as Epithemia adnata, E. turgida, Rhopalodia gibba and Rhopalodia rhopala in-combined with frequent occurrence of epiphytic and benthic freshwater forms and low amounts of brackish water species. The diatom assemblage reflects the influence of freshwater inflow from the el-Serw drain and el-Enaniya canal to the lake to form a shallow, mesotrophic to eutrophic, freshwater environment with increased alkalinity.

\section{Conclusion}

Manzala Lake surface sediments contain diverse and abundant, well to moderately preserve diatom assemblages. There is a certain degree of variation in diatom species composition between the studied sites within the lake. In the northern part, the marine polyhalobous taxa dominate the assemblages whereas the mesohalobous species seem to be important in eastern area and the freshwater forms dominant the western part and associated with some brackish forms in the southern area. The studied sampling sites are grouped by cluster analysis into five zones. Each of these zones occupied a distinct diatom assemblage that displaying certain environmental conditions. Salinity played a certain role controlling the distribution abundances of diatoms in Manzala lake. The predominance of benthic species reflects 
shallow water habitats, and the epiphytic taxa explained developed microphytes in particular at southern area. Moreover, both the sea water intrusion and treated/untreated polluted fresh water drained into the Lake Manzala display a major role in the diatom composition, distribution and dominant species.

\section{References}

Abbassy, M. S., Ibrahim H. Z. and Abdel-Kader, H. M. (2003). Persistent Organochlorine Pollutants in the Aquatic Ecosystem of Lake Manzala, Egypt, Bull. Environ. Contam. Toxicol, 70: 1158-1164.

Abdel-Baky, T. E., Hagras, A. E., Hassan, S. H. and Zyadah, M. A. (1998). Environmental impact assessment of pollution in lake Manzalah , 1Distribution of some heavy metals in water and sediment. J. Egypt. Ger. Soc. Zool, 26(B): 25-38.

Abdel Baky, T. E. and Zyadah, M. A. (1998). Effect of accumulation of copper, cadmium and zinc on some biological parameters of some marine fishes from the northern region of Lake Manzala, Egypt. J. Egypt. Ger. Soc. Zool, 27(B): 1-19.

Abd El Satar, A. M. (2001). Environmental studies on the impact of the drains effluent upon the southern sector of Lake Manzala, Egypt, Egypt. J. Aquat. Biol. and Fish., 5(3): 17- 30.

Badawy, M. I., Wahaab, R. A. and Abou Waly, H. F. (1995). Petroleum and chlorinated hydrocarbons in water from Lake Manzala and associated canals. Bull. Environ. Contam. Toxicol, 55: 258-263.

Butzer, K.W., 1976. Early Hydraulic Civilisation in Egypt, a Study in Cultural Ecology. The U niversity of Chicago Press, Chicago

Battarbee R.W., Anderson N.J., Jeppesen E. \& Leavitt P.R. (2005) Combining palaeolimnological and limnological approaches in assessing lake ecosystem response to nutrient reduction. Freshwater Biology, $50,1772-1780$

Cleve-Euler, A. (1953). Die Diatomeen von Schweden und Finnland. Teil III. Monoraphideae, Biraphideae 1. Authorized Reprint 1968, Bibliotheca Phycologica, Band 5, J. Cramer, Lehre.

De Wolf, H. 1982. Method of coding of ecological data from diatoms for computer utilization. Med. R. Geol. Dienst. 36: 95-99.

Denys, L. 1991-1992. A check-list of the diatoms in the Holocene deposits of the western Belgian coastal plain with a survey of their apparent ecological requirements. I. Introduction, ecological code and complete list. Geol. Surv. Belg. Prof Paper 246: 141 .
Dowidar, A. A. and Hamza, R. W. (1983). Primary productivity and biomass of Lake Manzala. Rapp. Comm. Int. Mer. Medit, 28: 6-12.

Ehrlich, A. 1973. Quaternary diatoms of the Hula Basin (Northern Israel). Bull. Geol. Surv. Isr. 58: 1-39.

Ehrlich, A. 1975. The Diatoms from the surface sediments of the Bardawil Lagoon (Northern Sinai)Paleo-ecological significance. Nova Hedwigia 53: 253-277.

Ehrlich, A. and R. Ortel. 1979. The influence of salinity on the benthic diatoms communities of the Lower Jordan river. Nova Hedwigia 64: 325-336.

El-Bokhty, E. E. B. (1996). Distribution of bottom fauna in Lake Manzala in relation to prevailing environmental conditions. M. Sc. Thesis, Fac. Sci. Tanta Univ., Egypt, 124pp.

El-Enani, H. R. (2004). Ecological and biological studies on Lake El-Manzala with special reference to their water quality and sediment productivity. $M$. Sc. Thesis, Fac. Sci., Al Azhar Univ., 358 pp.

El-Ghobashy, A. E. (1990). Bilological studies on the Western region of Lake Manzala, Ph.D. Thesis. Fac. Sci. Mans. Univ., 279 pp.

El-Rakaiby, M. L. and Youns, H. A. (1993). Morphological and temporal studies of Manzala Lake area and Damietta-Port Said Coast, Egypt using remote sensing Technology. Egypt J. Remote Sensing, (1): 55-66.

El-Wakeel, S. K. and Wahby, S. D. (1970). Bottom sediments of Lake Manzalah, Egypt. J. sediment. Petrol, 40(3): 480-496.

Fathi, A. A. and Abdelzahar, H. M. A. (2003). Limnological studies on the wetland Lake ElManzala, Egypt, Bull. Fac. Sci. Assiut. Univ., 32(2D): 215-233.

Fathi, A. A., Abdelzahar, H. M. A., Flower, R. J., Ramdani, M. and Kraiem, M. (2001). Phytoplankton communities in North African wetland Lakes, the CASSARINA Project. Aquatic Ecology, 35 (3-4): 303-318.

Flower, R. J. (2001). Change, stress, sustainability and aquatic ecosystem resilience in North African wetland lakes during the 20th century: an introduction to integrated biodiversity studies within the CASSARINA Project. Aquatic Ecology, 35(3-4): 261-280.

Foged N. (1980). Diatoms in Egypt. Nova Hedwigia, 33:629-707.

Foged, N. 1993. Some diatoms from Siberia, especially from Lake Baikal. Diatom Res. 8: 231-279 
Gasse, F., Barker, P., Gell, P.A., Fritz, S.C., Chalie, F., 1997. Diatom-inferred salinity in palaeolakes: An 375 indirect tracer of climate change. Quaternary Sci Rev 16, 547-563.

Frihy, O. E., Dewidar, K. M. and El Banna, M. M. (1998). Natural and human impact on the northeast Nile delta coast of Egypt. Journal of coastal Research, 14: 1109-18

Gasse, F. (1986). East African diatoms. Taxonomy, ecological distribution. Biblioth. Diatomol, 2: 1-201.

Hammer, Ø., D.A.T. Harper and P.D. Ryan. 2001. Past: paleontological statistics software package for education and data analysis. Palaeontol Electr 4: 1 9.

Hemphill-Haley, E. 1995. Diatom evidence for earthquake-induced subsidence and tsunami $300 \mathrm{yr}$ ago in southern coastal Washington. Geol. Soc. Am. Bull. 107: 367-378.

Hendey, N.I. 1964. Bacillariophyceae (diatoms), Part V. In: An introductory account of the smaller algae of British coastal waters. $V$. Bacillariophyceae (diatoms). Fishery Investigations Series IV. H.M. Stationary Office, London. pp. 1-317.

Hustedt, F. (1930). Bacillariophyta (Diatomae). In: A. Pascher: Die Süsswasser-Flora Mitteleuropas, 10: 466.

Hustedt, F. 1927-1966. Die Kieselalgen. In: (L. Rabenhorst editor) Kryptogamenflora von Deutschland, Oesterreich und der Schweiz, Akademische Verlagsgesellschaft, Leipzig, Bd. 1: pp. 1-920, Bd. 2: pp. 1-845, Bd. 3: pp. 1-816.

Hustedt, F. 1957. Die Diatomeenflora des Fluss-systems der Weser im Gebiet der Hansestadt Bremen. Abh. Nat. Ver. 34: 181-440.

Juggins, S. 1992. Diatoms in the Thames estuary, England: ecology, palaeoecology, and salinity transfer function. Bibl. Diatomol. 25: 1-216.

Khalil, M. T. (1990). The physical and chemical environment of Lake Manzala, Egypt. Hydrobiol, 196: 193- 199.

Khalil, M. T. and Bayoumi, A. R. (1988). Fishery assessment survey of Lake Manzala, Egypt, Bull. Nat Inst. Oceanogr. \& Fish., ARE, 14(3): 139-154.

Khalil, M. T. and El-Awamri A. A. (1988). Plankton organisms as bio indicators for organic pollution at the southern area (El-Genka) of lake Manzala, Egypt. The First National Conference on Environmental Studies and Research- June 1988 Cairo, Egypt.

Krammer, K. and H. Lange-Bertalot. 1986-1991. Bacillariophyceae. In: (H. Ettl, J. Gerloff, H. Heynig, and D. Mollenhauer eds) Süsswasser-flora von Mitteleuropa. 2/1. pp. 1-876, 2/2. pp. 1-596, 2/3. pp. 1-576., 2/4. pp. 1-437. Gustav Fischer Verlag, Stuttgart and New York.

Lange-Bertalot, H. (1979): Simonsenia a new genus with morphology intermediate between Nitzschia and Surirella. -Bacillaria 2: 127-136.

Lange-Bertalot, H. (2000): Transfer to the generic rank of Decussata Patrick as a subgenus of Navicula Bory sensu lato-Iconogr. Diatomol. 9: 670-673.

Lange-Bertalot, H. (2001): Navicula sensu stricto - 10 genera separated from Navicula sensu lato Frustulia. - Diatoms of Europe 2: 1-526. Gantner Verlag, Ruggell.

Mölder, K. and Tynni, R. (1970). Über Finnlands rezente und subfossile Diatomeen IV. Bull. Geol. Soc. Finland, 42: 129-144.

Pankow, H. (1976). Algenflora der Ostsee. II. Plankton, $493 \mathrm{pp}$.

Patrick, R.M. and Reimer, C.W. (1966). The diatoms of the United States exclusive of Alaska and Hawaii. Monographs of the Academy of Natural Sciences of Philadelphia, 1: $688 \mathrm{pp}$.

Patrick, R.M. and Reimer, C.W., 1975. The diatoms of the United States exclusive of Alaska and Hawaii.Monographs of the Academy of Natural Sciences of Philadelphia 2: $213 \mathrm{pp}$.

Rakowska B., 2001, Studium różnorodności okrzemek ekosystemów wodnych Polski niżowej [Study of diatom diversity in water ecosystems of Poland's lowlands], Wydawnictwo Uniwersytetu Łódzkiego, Łódź, $75 \mathrm{pp}$.

Ramdani, M., Elkhiati, N., Flower, R. J., Thompson, J. R., Chouba, L., Kraiem, M. M., Ayache, F., Ahmed, M. H. (2009). Environmental influences on the qualitative and quantitative composition of phytoplankton and zooplankton in North African coastal lagoons. Hydrobiologia 622:113-131

Round, F.E., R.M. Crawford and D.G. Mann. 1990. The Diatoms. Biology and Morphology of the Genera. 1st edition. Cambridge University Press, Cambridge. pp. 747.

Said, R. (1962). The gelogy of Egypt. - Elsevier, New York, $377 p$

Simonsen, R. 1962. Untersuchungen zur Systematik und Okologie der Bodendiatomeen der westlichen Ostsee. Int. Rev. Ges. Hydrobiol. Syst. Beih. 1: 1-144.

Simonsen, $R$. 1979. The diatom system: Ideas on phylogeny. Bacillaria 2: 9-72. 
Steinberg, C. and Schiefele, S. 1988. Biological indication of trophy and pollution of running waters. 2. Wasser-Abwasser-Frosch., 21: 227-234.

Stoermer, E.F. and J.P. Smol. 1999. The diatoms: Application for the environmental and earth sciences. 1st edition. Cambridge University Press, London. pp. 456.

UNDP, 1997. Governance for Sustainable Human Development: A UNDP Policy Document. United Nations Development Programme 40 pp.

Vos, P.C. and H. De Wolf. 1993. Diatoms as a tool for reconstructing sedimentary environments in coastal wetlands; methodological aspects. Hydrobiologia 269/270: 285-296.

Wahby, S. D., Youssef, S. F. and Bishara, N. F. (1972). Futher studies on the hydrography and chemistry of Lake Manzalah. Bulletin of the Institute of Oceanography and Fisheries, 2: 401-422, Egypt.

Yacoub, A. M., Siliem, T. A., Kadry, S. M. and Mabrouk, D. B. (2005). Effect of drainage water on the chemical characteristics of Lake Manzala waters, Egypt. J. Egypt. Acad. Soc. Environ. Develop., (DEnvironmental Studies), 6(1): 133-152.

Zalat, A. A. (2000): A new naviculoid diatom species Navicula aegyptiaca with two new varieties from Holocene sediments of brackish lakes in Egypt. Neues Jahrbuch für Geol. and Palaeont. Mh. 8, 485498.

Zalat, A.A. 2002. Distribution and origin of diatoms in the bottom sediments of the Suez Canal lakes and adjacent areas, Egypt. Diatom Res 17/1: 243-266.

Zalat, A.A. 2015. Holocene diatom assemblages and their palaeoenvironmental interpretations in Fayoum depression, Western Desert, Egypt, Quatern. Int. 369: $86-98$.

Zalat, A.A. and S. Servant-Vildary. 2005. Distribution of diatom assemblages and their relationship to environmental variables in the surface sediments of three northern Egyptian lakes. J. Paleolimnol 34: 159-174.

Zalat, A.A. and S. Servant-Vildary. 2007. Environmental change in Northern Egyptian Delta lakes during the late Holocene, based on diatom analysis. J. Paleolimnol 37: 273-299. 